Katarzyna KUKOWSKA

Sebastian SKOLIK

\title{
2.3. SHARING THE COMMON GOOD IN THE SOCIAL NETWORKS
}

\begin{abstract}
Summary
Interest in social capital in various teachings, as a consequence, boils down to an analysis of the benefits to individuals and communities and related interpersonal relationship and institutional networks. The literature used indicates that social capital is a common good, not private or public, regardless of whether it is located in the communities of organizations or community nature. It is treated as a resource in addition, anchored in the network, from which they can benefit people with access to the network. The aim of this article is to attempt to answer a number of questions regarding the sharing of social capital, taking into account an interdisciplinary approach to issues. According to Emerson's and Castells' conceptions, in the article has been done the analysis of theoretical recognition of social networks within comparing of the network with other forms of social organization: hierarchies, markets and communities. The concept of the flow of social networks has been referred to assumptions of social capital and the new institutionalism.
\end{abstract}

Keywords: common good, social capital, social networks

\section{Introduction}

The flow of resources within social networks has been analyzed by a number of various researchers originating mainly from the environment of economists and sociologists. These approaches were not only different, but also did not take into account the previously developed ideas. In the following article the authors attempt to present and use various approaches for analysis of a problem of creating access and flow of the resources within the structures of the social networks.

Taking into account the approach by one of the first theoreticians of capitalism, K. Marks, it was based on the dialectical materialism. Power, politics and symbolic culture as the superstructure developed and have changed depending on the changes of the material base. Therefore, social capital seems not to have the material background. The research results in the area of sociobiology and evolutionary psychology prove that significant amount of the patterns of human behaviours are effects of the evolution of the species (Buss, 2003; Wilson, 2000). Although the approaches referring to the biological evolution are not the same as ideas claiming that the basis for the social change is material culture, in both cases what is symbolic is also dependent on the material (physical) background. With reference to that, it may be assumed, that it refers also to the ways of creating relationships within social networks.

The case of resources and their flow, including social, culture or symbolic capital, becomes more significant in the concepts of the organization management. It is worth 
considering that within organizations there also exist informal and formal structures. Because social capital is connected with informal structures, formal structures may be treated as fixed forms of social capital.

It may be presumed, that transactions with the use of resources, from the psychological point of view, to a significant extent are based on the stable scripts (cliche), which is in opposition to the postulate of the network openness for enriching the social capital. Interpersonal relationships take the form of transactions, in which profit (pay) is a psychological advantage (pat) (Berne, 1987, pp. 9-10). Individuals create and replicate in the further generations schemas (scripts) allowing them to maximize psychological profits. From the perspective of the cultural evolution, a human being and social networks are structures allowing replicating of such types of schemas, if they are profitable for strengthening of these structures (biological, structural and economic). A part of these duplicated schemas may be destructive for individuals and the groups. As a result individuals and groups the least adapted to the environment loose the possibility of replicating of their own schemas. Each individual belonging to smaller or bigger networks, function according to the relationships allowing to dichotomous thinking according to the categories "we" and "they" that allows establishing the boarders of social networks. According to the sociological approach, social order is generated thanks to the shared (internalized) axionormative order. Taking the perspective of cultural evolution it may be presumed that social networks, as well as the individuals belonging to them, accept from the outside the schemas, values and norms that strengthen existing structure (Biedrzycki, 1998, pp. 191-198). It concerns both conscious systems of values and norms as well as unconscious schemas. Openness therefore should not be convergent with declared attitudes towards openness on social, cultural or economic environment. It may be a result of the profits for replicating of the cultural patterns in the area of a given structure organized in a form of network.

There is a question to what extent the members of the network consciously calculate their participation in the resources (goods), and to what extent they are influenced by unconscious schemas of behaviours, that give them psychological profits. E. $g$. workaholism allows to earn high psychological profits, allowing at the same time to earn great profits for an organization. If people support the agents who are workaholics, they accept their game and such a structure (based on workaholism) may be very durable because of the generated goods. In case of a high level of bureaucracy, workaholism oriented on (mechanic) repetition of the action does not have to lead to the use of economic goods, but generates and strengthens specific forms of behaviour.

\section{Resources and social networks - modern approach in the humanistic science}

Aiming to possess resources is one of the basic motivations in the economic activities of a human being. Such approach refers to the issue of economic capital, nevertheless the notion of a good may be also referred to social capital. It is significant that according to the idea of social capital, the access to the common goods is considered in the context of their position within the network of social relationships. The members of 
the networks of interpersonal relationships activate capital accumulated within these networks, at the same time they become beneficiaries of the goods located in the network.

The idea of network became pretty popular in the texts from the field of social sciences together with the development of digital technologies and the Internet. The precursory research methodology concerning social networks was initiated in a form of sociometry by Moreno in the first half of the 20th century (Bendyk, 2004, pp. 261267). Whereas advanced network analysis has been developed since the 1970s (Turner, 2004, p. 604). Średnicka, following Tapscott (1996, p.18) claims that the first decade of the 21 st century initiates the era of networked intelligence, which may lead to creation of new economic structures and new society (Średnicka, 2011, p. 98). On the other hand, A. Słocińska, while characterizing the scientific approach to the organized forms of human activity, links logic of networking to performative approach. According to this approach, for functioning of collective entities, people and their behaviours are more important than structures and features of an organization (Słocińska, 2012, pp. 478-479).

\section{Participation in the interpersonal relationships in the social networks}

Not all the relationships within the networks are symmetrical in terms of the actors taking part in the resources exchange. Emerson marks two types of the relationships of exchange: unbalanced - connected with the power of one actor over the other one, and balanced, connected with equation of the position towards power. Power is a result of a favourable access to the resources by one of the actors, and dependency of the exchange partner on him. Equation of the positions is based on:

- becoming independent by the actor "handicapped" in terms of the power possessed by limiting of the value of resources possessed by an exchange partner, or increasing of the own resources (finding other partners for exchange);

- making privilege in terms of possessed power partner of exchange dependent by increasing the value of own resources, or decreasing the amount of the sources of resources for this particular partner. (Turner, 2004, pp. 326-327).

Social capital, the basis of which is a network of social relationships, is created on the basis of mutual trust as well as mutual obligations (Stelmaszczyk, 2011, p. 24). They foster creation of the information- flow networks. Paradoxically, network structure in particular cases is being created from the group of people not aiming to create such a network. An example of such a structure may be a group of people joining the network of Multi Level Marketing, initially as consumers (Bazan-Bulanda, 2014, p. 372). Structures of MLM created by the system of registration of individuals in the Internet portal become exclusive towards people digitally excluded. Analyzing network organizations in the broad context, some authors even claim, that trust in such organizations is short-term and depersonalized (Bylok, 2014, p.146). It may concluded that a long-reaching consequence of network openness may cause loss of trust. M. Stelmaszczyk proves, that trust noticeable while expressing oneself, is dependent on the circumstances and the strength of ties within the network (Stelmaszczyk, 2011, p. 28). Nevertheless, A. Słocińska advocates, that in the networks there is no space for 
people characterized by Machiavellianism. People showing such type of behaviours, especially blocking the flow of information, are rejected (Słocińska, 2012, p. 477). Therefore, it may be assumed that social groups organized in a form of a network are able to deal with the "free riders", whose actions could lead to loss of trust. Hence, trust cannot be a short-term phenomenon in case of opening of a network. It should be rather presumed, that maintaining trust with simultaneous opening of the network requires existence of a permanent root. An effect of this is „crystallization” (stiffening) of a social network (Skolik, 2014, pp. 166-167). What is worth mentioning is the point of view presented by Yamagishi and Cook, who claim that the greater is the network, the lower are the costs of occurrence of the "free riders" within its structures. What is characteristic among authors is existence of the reciprocal exchange within the networks (with postponement of the reward for future time), where the resources are passed among the actors sequentially. It generates some of the properties of a network exchange (Turner, 2004):

- breaking of the „exchange chain” may lead to decay of the network;

- actors directly linked are more willing to cooperate;

- permanent controls meaning high possibility of catching „free riders" within the chain of the exchange relationships.

According to this concept of creating trust, it is a result of constant, reciprocal supervision and expecting the action according to the accepted rules. The network structure, therefore may influence the use of the Machiavellian strategies. What is connected to that, the level of trust is influenced not only by the axionormative system of the network members, but also their personalities and structural (morphological) aspect of the network.

According to Stelmaszczyk, in order to have the relationships among partners existing, including trust, they have to be attractive for each other, and the type of attractiveness is dependent on similarities in various dimensions (Stelmaszczyk, 2011). The author also indicates some of the biological factors (biological similarity). Such an approach may be ethically problematic because of the possibility of "reviving" the racist ideas. Nevertheless, a great deal of the research proves that interpersonal attractiveness has biological background (Pawłowski, 2009). Also skeptical attitude to the aspect of trust within the network is presented by J. Średnicka, who claims that webbyness leads to the increase in the frequency of relationships ad hoc (in relations with not necessarily attractive "strangers"), and by this- to the tensions and uncertainty (Średnicka, 2011). Every new user of the network is a potential rival in the access to the goods. According to R. M. Emerson the tensions within the network are results of not only the frequency of relationships between heterogeneous actors, but asymmetry within their positions towards access to power and access to the resources. Extreme case of asymmetry in the relationships is one-sided monopoly. It occurs when the actors disposing one type of a good become alternative for the actors possessing other types of goods. At the same time, such an actor has an advantage in power over the remaining actors. Such a relation is unstable and it is presumed that the actors exchanging the goods with the monopolist will aim to balance the positions (Turner, 2004). One of the ways of obtaining balance is "division of labour" where actors exchanging goods with a monopolist start diversifying in terms of the delivered items (Turner, 2004, p. 330). 
Assuming, that the network has its permanent root (the most active and relatively the longest functioning members in a given network), every new member is treated the same way, and their different values may be potential resources for social capital. What is more, rather for people joining the group, created relationships in the network may seem to be full of tensions and ambiguities. It would be also difficult to agree that with the risk arising from interdependence of many networks, members involved in the networks every single time have to discuss the matters concerning binding decisions (Średnicka, 2011, pp. 102-104). Sometimes the loss of access to the resources of the social capital may be the lower cost than the use of energy and psychological costs connected with the decision making process.

The engagement and positive emotions may also be treated as the resources. Lawler and Yoon in a model confirmed by the results of the experiments present the following set of interdependencies (Turner, 2004, pp. 382-383):

- if in the relations of exchange the power is total (sum of mutual interdependencies) is significant, and relative power (difference between mutual interdependencies) is low, the frequency of exchange will be significant.;

- significant frequency of exchanges leads to appearance of positive emotions in the exchange (e.g. excitement caused by future rewards or satisfaction caused by the finalized exchange);

- positive emotions foster consistency of relationships;

- finally, consistency of relationships catalyze such behaviours as: bestowing with gifts, maintaining the relationships and taking part in the common projects.

Relationships of exchange may undergo the process of objectization, which means independently from the resources exchange, the process itself will be a reward for the actors. On the other hand L. Molm considering the problem of justice and punishment in the exchange processes, it may be concluded that the actors will rather try to avoid losses. It means that in reciprocal exchange, individuals will attempt to maintain the status quo and will not risk with the behaviours that may bring losses (Turner 2004).

Taking into account the above mentioned approach, the tensions within the network and negative emotions will be reduced within the networks in which exchange acts will be reciprocated and too little extent will lead to structural advantage of some of the actors over the rest, at the same time influencing positively their mutual interdependencies. Such a model of network may be considered as stable, therefore to little extent prone to decay. What is worth considering is the need of such a model in the optimization of functioning of modern organizations.

\section{Social network structures vs. hierarchy}

The key elements of the networks are the nodes, defining their spatial structure. The nodes are described as points, and in order to limit the level of theoretical abstraction, it may be also presumed as people, social positions, or actors (concerning also collective actors). The next aspect of the network structure concerns connections between the nodes that in the idea of social capital lead to the synergy effect. The connections (links) are characteristic by the flow of resources of three types (Turner, 2004): (1) material (physical objects); (2) symbols (e.g. ideas, values, norms) and (3) feelings (e.g. approval, pleasure). 
In the initial studies concerning interpersonal relationships J. Moreno focused mainly on the emotional states (Turner p. 605) creating the sociometry technique (Brzeziński, 1984 , p. 287). Material and symbolic resources may be treated as the resources of material and symbolic culture, but feelings (emotions) as social resources. W. Dyduch claims that failure to build the relationships between the participants of the network may stop the development of innovation and initiative (Dyduch, 2011, p. 24). It is worth considering, to what extent the strength of the ties (intensity of involvement and frequency of relationships), would be optimal for innovative activities. In accordance with the ideas referring to the problem of social deviations, innovations are the main deviations towards conformist activities (Merton, 2002, pp. 206-242). Whereas conformism is both an effect of creating strong relationships, as well as avoiding risky (innovative) behaviours. Innovation would therefore be a factor destabilizing the network, if it would cause increase in asymmetry in relationships between the exchange partners.

Apart from the above mentioned aspects of the network structures, in its description the following parameters are taken into account: network density, size, centralization, heterogeneity (Bylok, 2013, p.159). In the network analysis, apart from the above mentioned parameters, there are also other configurations of links and connected to them morphological properties: (Turner, 2004, pp. 607-612):

- number of links;

- direction of the flow (including degree of reciprocity of links);

- transitivity of the links (passing the resources to the further actors within the chain of interconnections);

- in case of the density of links, the cliques are considered as local densities;

- strength of the links (frequent flow of many resources);

- bridges (links connecting local densities);

- intermediaries (nodes mediating between various local densities, that are usually characterized by actions aiming to block the links between the local densities);

- in case of centrality it is defined as the property of a node based on linking with many intermediaries;

- equivalence meaning identity of the relationships of some actors towards others.

Besides the structural dimension of social capital presented this way, there are also discussed cognitive approaches referring to the organizational culture and relational approach - connected with the rules and trust (Nahapiet, Ghostal, 1998, pp. 252-256). Dependently on the configuration, network may have more egalitarian, or more hierarchical form. In case formal organizations, hierarchical networks are characterized by lower density, and a manager is a clear, central node. In case of egalitarian networks there are not any clear nodes - there is no center, and managers are relatively more distanced towards personnel (Bylok, 2013, pp. 161-163). Such forms may be analyzed methodologically as ideal types, from which the intermediate models may be constructed. If, thanks to the development of modern technologies, the space became shrunken and caused progressive thickening of the network structure (Słocińska, 2012), it may be concluded, that such phenomenon would lead to gradual equalization of social networks in the organizations. 
According to Średnicka ,[at] the level of a country and organization various networks intersect and it is not possible to have them organized in a form of a hierarchical structure" (Średnicka, 2011, p. 101). It would be hard to say whether in fact the size of a network and dissemination of networking could lead to simultaneous disappearance of hierarchical structure. Even in the network environment of a cyberspace, which is not orderly, locally emerge and strengthen hierarchies (Skolik, 2012, pp. 129-132). In the companies of network marketing, they are formally lack of management staff (Bazan-Bulanda, 2014, p. 369). It should be presumed that in MLM the managing functions are acted by people in the roles of mentors, patrons, teachers and many other roles created in order to highlight the community nature of such organization.

According to the sociological theory, there may be distinguished four forms of organizational structures: communities, hierarchies, networks and markets (Stalder, 2012). Referring to the questions of hierarchy and egalitarianism, in the ideas of Castells, Urry and Musso network structures in comparison to the remaining forms of organization, are characterized by the following properties (Stalder, 2012):

(1) If the markets are treated as a sum of actions of various individuals (actors), in case of the network the nodes are defined by the whole structure of links. For the nodes of the network, the consequences of the entrance to the structure, or leaving the structure are more significant than in case on entering or leaving the market. The markets are impersonal ideal types, whereas networks are ideal ,personal” types - apart from the significant autonomy, the nodes are linked with more clear personal relationships.

(2) Hierarchies are defined as permanent structures of management and controls, whereas in the networks there occurs constant adjusting to the developed interaction patterns (more durable than in the market) and permanent re-defining of the network participants. Because of the lack of formal authority, conflicts are resolved by negotiations, or by reference to the external authorities. Structures of interconnections within the networks are relatively unstable, and configurations of the links are dependent on the dynamics of the impacts of the nodes and characteristics of the internal patterns of interactions.

(3) Comparing to hierarchies and markets, networks provide individuals with the greater rank of subjectivity, similarly to the structures. In contrast to the community:

- networks do not minimize heterogeneity;

- individuals are more autonomous towards the whole (it is more easy to enter and leave network than in case of communities);

- networks are more asymmetric (informal hierarchies are created);

- networks are integrated around the common aim of ,unequal” nodes;

- axionormative system in the network is the reference point for interacting units.

\section{Access to the common resources within the network structures}

The essence of functioning of social networks is potential identified with social capital (Bartkowski, 2007), where interpersonal relationships generate connections between the resources. They are activated and ,socialized" within the networks of social capital (Bartkowski, 2007, p. 84). According to scientific literature, activating of resources is connected with the issue of diffusion of networking (Średnicka, 2011). As mentioned 
by Przybysz \& Sauś (2004) social capital was generated together with the development of democratic, free market (therefore development towards the direction of networks) environments. Nevertheless, it has to be assumed that network structures had been existing much earlier. Bendyk (2004) proves that some of the forms of webbyness appeared in the religious movements in the period of intensive action of inquisition.

Creating of the network structures secondarily contribute to the phenomenon of intercepting the resources located in the social relationships (Pogonowska, 2004, p. 24). The profit from the network is mostly earned by the communities creating common goods, but it may be also of some benefit for people, who to some smaller extent contribute to the production of social capital as well. According to Lin (1999) the networks originated as a result of common need for earning profits. With reference to the above mentioned sociological theory, such approach place the notion of network structures at the same level as market structures. From the neoliberal point of view, common goods are prone to be destroyed, or damaged, if they are not privatized. According to the „New institutionalism” common goods are not stored, or destroyed, if the communities using them: designate the borders for the place in which the goods will be located; adjust the rules to the local needs, but the rules may also be modified by the members of the communities; sanctions are graded and there is the possibility to monitor actions of individuals (Hofmokl, 2009, pp. 40-41). Here the question may be asked, whether any of the factors regulating the access to the common goods within homogeneous communities may be transferred into the rules of functioning of the axionormative system and system of sanctions within the networks.

Manufactured economic goods may be replaceable by other forms of capital, including social capital (Bartkowski, 2007). Transactions, therefore, transformations of various forms of capital into other forms, are connected with different costs that can limit the loose of action. At the same time, some of the costs may be borne in order to protect the rules of mutuality (Bartkowski, 2007). According to the classical approach by Bourdieu existing of social capital was the factor strengthening social inequalities with reference to the access, or lack of access to this capital. Some of the modern texts present the opposite approach, identifying creation of social capital with reciprocal altruism (Dziekański, 2011, p. 184). The issues discussed above concerning the aspect of the position of the individuals within the networks indicate that the networks are dynamic systems, it is common that there may take place the process of blocking of the resources by the brokers, but also altruism may appear among the nodes aiming to limit the position of the central actor.

\section{Conclusions}

On the basis of the literature study the following conclusions were formulated:

- What may influence the level of trust is not only the axionormative system of the network members and their personalities, but also structural (morphological) aspect of the network.

- Perceiving of the tensions within the network is not caused by the fact that the relationships are established among the new members, but because of the fact that 
the new members may perceive networks as full of tensions and misunderstandings.

- Model of a network may be considered as stable (to little extent prone to decay) if 1) tensions and negative emotions are reduced, 2) acts of exchange are reciprocal and to little extent generate structural inequalities, at the same time 3) having positive influence on mutual dependence of the actors

- Innovation may destabilize the network, if it leads to the increase in the asymmetry of the relationship between the exchange partners.

- Network as a dynamic system is a form of organization of the activities standing out and combining forms existing on the markets, within organizations as well as in the communities. This dynamics does not allow to state clearly, to what extent morphology of a network may lead to the given proportion of the egoistic and altruistic (selfish and selfless) behaviours.

If cooperation reduces risk, it is not because of elimination of deviant behaviours, but because of limited tolerance. Existing rules within the respectively stable networks are not reified, but always socially negotiated. Otherwise, it would cause closing the communities in the state of lack of trust and ostracism against the new members. If the models of cooperation are cultural matrix, it does not mean that they are ,monolith". In the network environment the certain patterns of behaviour that effect in supporting and enriching of the resources have greater chances to survive. If the social capital enables innovations, it happens thanks to the possibility of using common goods, including knowledge about mistakes. For survival of the network of resources of social capital there should be kept greater balance between chaos of deviations, and stagnation of normative order.

\section{References}

1. Bartkowski, J. (2007): Kapitał społeczny i jego oddziaływanie na rozwój w ujęciu socjologicznym. In: Kapitał ludzki i kapitał społeczny a rozwój regionalny, ed. M. Herbst, Scholar, Warszawa, pp. 54-97.

2. Bazan-Bulanda, A. (2014): Rola Internetu w rozwoju marketingu sieciowego (studium przypadku). In: Współczesny marketing i logistyka - globalne wyzwania, eds. K. PieniakLendzion, T. Nowogródzka, Wydawnictwo Uniwersytetu Przyrodniczo-Humanistycznego w Siedlcach, Siedlce, pp. 367-379.

3. Bendyk, E. (2004): Antymatrix. Człowiek w labiryncie sieci, Wydawnictwo W.A.B., Warszawa, $344 \mathrm{p}$.

4. Berne, E. (1987): W co grają ludzie? Psychologia stosunków międzyludzkich, PWN, Warszawa, $205 \mathrm{p}$.

5. Biedrzycki, M. (1998): Genetyka kultury, Prószyński i S-ka, Warszawa, 256 p.

6. Brzeziński, J. (1984): Elementy metodologii badań psychologicznych, PWN, Warszawa, $348 \mathrm{p}$.

7. Buss, D.M. (2003): Psychologia ewolucyjna, Gdańskie Wydawnictwo Psychologiczne, Gdańsk, 464 p. 
8. Bylok, F. (2013): Kapitał społeczny jako czynnik rozwoju szkoły wyższej. In: Edukacja Praca - Kariera. 40 lat Polskiej Pedagogiki Pracy, eds. F. Szlosek, H. Bednarczyk, Wydawnictwo Naukowe Instytutu Technologii Eksploatacji - PIB, Warszawa - Radom, pp. 157-168.

9. Bylok F. (2014): Globalizacja i sieciowość a zaufanie społeczne na współczesnym rynku. In: Perspektywy rozwoju społeczeństwa sieciowego w Europie Środkowej i Wschodniej, ed. S. Partycki, Wydawnictwo KUL, Lublin, pp. 139-147.

10. Dyduch, W. (2011): Rozwój organizacji Górnego Śląska w oparciu o kapitał społeczny i przedsiębiorczość. In: Od badania do działania. Analiza trendów rozwojowych i zmian gospodarczych w obszarze Górnośląskiego Związku Metropolitalnego, eds. M.S. Szczepański, G. Gawron, P. Rojek-Adamek, WSzZiNS w Tychach, Tychy, pp. 23-39.

11. Dziekański, P. (2011): Konwersja kapitału społecznego a ekonomia instytucjonalna w aspekcie rozwoju regionu. In: Kapitał społeczny w organizacji i regionie, eds. F. Bylok, A. Czarnecka, Wydawnictwo Politechniki Częstochowskiej, Częstochowa, pp. 170-189.

12. Hofmokl, J. (2009): Internet jako nowe dobro wspólne, Wydawnictwa Akademickie i Profesjonalne, Warszawa, $248 \mathrm{p}$.

13. Lin, N. (1999). Building a Network of Social Capital, „Connections”, 22, pp. 28-51.

14. Merton, R. K. (2002): Teoria socjologiczna i struktura społeczna, PWN, Warszawa, 670 p.

15. Pawłowski, B. ed. (2009): Biologia atrakcyjności człowieka, Wydawnictwo Uniwersytetu Warszawskiego, Warszawa, $345 \mathrm{p}$.

16. Pogonowska, B. (2004): Kapitał społeczny - próba rekonstrukcji kategorii pojęciowej. In: Kapitał społeczny - aspekty teoretyczne i praktyczne, ed. H. Januszek, Wydawnictwo AE w Poznaniu, Poznań, pp. 120-126.

17. Przybysz, J. \& Sauś, J. (2004): Kapitał społeczny. Szkice socjologiczno - ekonomiczne, Wydawnictwo Politechniki Poznańskiej, Poznań, 133 p.

18. Skolik, S. (2012): Partnership and Lidership as Main Relantionship in Wikimedia Projects. In: Human Resource Management and Corporate Competitiveness, eds. Cs.B. Illés, F. Bylok, A. Dunay, Szent Istvan University Publishing, Gödöllö, pp. 124-134.

19. Skolik, S. (2014): Ład organizacyjny a ład przestrzenny. Rola interfejsu w organizacji pracy internetowych wspólnot działań. In: Wybrane problemy zarządzania zasobami ludzkimi we współczesnych organizacjach, eds. A. Bazan-Bulanda, E. Robak, WWZPCz, Częstochowa, pp. 160-169.

20. Słocińska, A. (2012): Sieci jako czynnik kształtowania przedsiębiorczości w performatywnym ujęciu organizacji, „Zeszyty Naukowe Ekonomiczne Problemy Ustug Uniwersytet Szczecinski", 724, pp. 475-485.

21. Nahapiet, J.; Ghostal S. (1998): Social capital, intellectual and capital and the organizational Advantage, „The Academy of Management Review”, 23(2) pp. 242-269.

22. Stelmaszczyk, M. (2011): Menedżer a wpływ kultury organizacji na zarządzanie kapitałem społecznym w małym przedsiębiorstwie. In: Kapitał społeczny w organizacji i regionie, eds. F. Bylok, A. Czarnecka, Wydawnictwo Politechniki Częstochowskiej, Częstochowa, pp. 22-33.

23. Średnicka, J. (2011): Indywidualizacja i dyfuzja sieciowości. Refleksje nad przemianami społeczno-kulturowymi, „Problemy zarzadzania”, Vol. 9, 2 (32), pp. 93-109.

24. Tapscott, D. (1996): The Digital Economy: Promise and Peril in the Age of Networket Intelligence, McGraw-Hill, New York, $416 \mathrm{p}$.

25. Turner, J. H. (2004): Struktura teorii socjologicznej, PWN, Warszawa, 734 p.

26. Wilson, E. O. (2000): Socjobiologia, Zysk i S-ka, Poznań, 360 p. 